\title{
INFLUENCE AGAINST RECEIVABLE MANAGEMENT \\ CAPABILITIES IN PRODUCING INCOME ON THE BASIC INDUSTRY AND CHEMICAL COMPANY SUB SECTOR FEED LISTED IN INDONESIA STOCK EXCHANGE
}

\author{
Edhi Asmirantho \\ Dosen Tetap Fakultas Ekonomi Universitas Pakuan \\ Resta Rosdiana \\ Mahasiswa Fakultas Ekonomi Universitas Pakuan
}

\begin{abstract}
:
This study was conducted to determine and demonstrate empirically the effect of accounts receivable management of the company's ability to generate profits on the company grounds and chemical industry subsectors recorded fodder in the Indonesia Stock Exchange. Each company has a complete data for 10 years in the period 2004 to 2013 . Technical analysis of using multiple regression analysis, the data processing using SPSS version20. The results showed receivable management firm base and chemical industry subsectors fodder IDX can be said is still not optimal. Receivables management fluctuating and rising slowly apparent from the Receivable Turnover (RTO), Receivable Turnover in Days (RTD) and Total Asset Turnover (TATO) are unstable and there are accounts receivable with a long lifespan. Based on the R-square is formed, the independent variables are able to explain the growth of return on investment of $69.3 \%$. Hypothesis testing using the F test showed F count $>$ F table $(19.579>2.975)$ with a significance value of $0.000<0.05$ indicates that Receivable Turnover, Receivable Turnover in Days and Total Asset Turnover simultaneously significant effect on Return on Investment. While testing the hypothesis using the $t$ test showed the value Receivable Turnover $(1.642<2.056)$ with significant value $0.113>0.05$ and Receivable Turnover in Days $(1.547<2.056)$ with significance $0.134>0.05$ where $t<t$ table and the value significant $>0.05$, which indicates that they do not affect the return on investment, while the Total Asset Turnover value condition $t>t$ table $(6.520>2.056)$ and a significant value $0.000<$ 0.05 indicates that positive and significant effect on Return on Investment.
\end{abstract}

Keywords: Activity, Profitability, Receivable Turnover, Receivable Turnover in Days, Total Asset Turnover, Return on Investment.

\section{Pendahuluan}

Piutang merupakan salah satu kegiatan usaha perusahaan yang terjadi akibat dilakukannya penjualan secara kredit. Dengan adanya penjualan secara kredit (piutang) maka perusahaan perlu melakukan pengelolaan piutang perusahaan. Laba perusahaan merupakan tujuan dari setiap perusahaan, untuk itu perusahaan harus bisa mengelola piutangnya dengan baik dan efisien agar keuntungan perusahaan dapat direalisasikan.Laba perusahaan dapat dikaitkan dengan peningkatan kinerja perusahaan dalam pemanfaaatan aktiva yang dimiliki perusahaan.(Asmirantho, 2013)

Receivable atau Piutang merupakan tagihan perusahaan kepada pihak lain sebagai akibat penjualan secara kredit. Pemberian kredit merupakan salah satu proporsi karena merupakan salah satu proporsi yang penting, karena merupakan bagian aktiva yang perusahaan yang besar, oleh karena itu keberhasilan suatu perusahaan tidak lepas dari campur tangan manajemen, karena manajemen merupakan bagian dalam perusahaan yang berhubungan dengan aktivitas perusahaan. Manajemen piutang adalah pengelolaan piutang agar 
kebijakan kredit mencapai optimal, yaitu tercapainya keseimbangan antara biaya yang diakibatkan oleh kebijakan kredit dengan manfaat yang diperoleh dari kebijakan tersebut.(Martono dan Harjito, 2010).

Menurut Keown and Martin (2005)Piutang merupakan suatu hal yang sangat erat kaitannya dengan aktivitas keuangan, karena di saat perusahaan melakukan penjualan kredit maka akan memunculkan piutang usaha tersebut. Piutang ini tertulis dalam aktiva lancar, piutang usaha ini sangat mendominasi rata-rata di dalam aktiva lancar, tentu sangatlah penting bagi perusahaan mengelola piutangnya sebab pengelolaan piutang secara efisien menentukan profitabilitas dan likuiditasnya.

Objek yang digunakan dalam penelitian ini adalah tiga perusahaan industri dasar dan kimia sub sektor pakan ternak yang tercatat di BEI yaitu PT. Charoen Pokphand Indonesia Tbk, PT. Japfa Comfeed Indonesia Tbk dan PT. Sierad Produce Tbk. Alasan peneliti memilih objek tersebut bahwa perusahaan masing-masing dilihat ratarata umur piutang yang dimiliki perusahaan tersebut memiliki jangka waktu yang panjang antara lain 90 hari, 120 hari dan 180 hari serta Perusahaan pun dipilih berdasarkan IPO sebelum tahun 2000 dan sesudah tahun 1990.Data keuangan lengkap selama 10 tahun dalam periode $2004-2013$.

\section{Landasan Teori dan Hipotesis}

Piutang usaha adalah jumlah uang perusahaan yang masih belum dibayar ke perusahaan oleh para pelanggan yang telah membeli barang atau jasa secara kredit (Van Horne and Wachowicz, 2005). Dalam mengelola piutang perusahaan harus memperhatikan beberapa hal yaitu mengendalikan jumlah piutang, pengadaan jumlah hari pengumpulan piutang serta evaluasi terhadap penagihan piutang apakah berhasil atau tidak.

Menurut Asmirantho (2013) Faktor-faktor yang mempengaruhi besarnya investasi dalam piutang yaitu 1) Penilaian resiko kredit 2) Tingkat perputaran piutang Adapun Resiko kredit adalah resiko tidak terbayarnya kredit yang telah diberikan kepada para pelanggan. Oleh karena itu banyak perusahaan yang berusaha mengurangi resiko kredit dengan memperhatikan lima "C" yaitu Character, Capacity, Capital, Collateral, dan Conditions. Dalam menentukan perputaran piutang perusahaan dapat dilakukan dengan melihat analisis laporan keuangan yaitu dengan menggunakan rasio aktivitas.Dalam penelitian ini, penulis menggunakan perputaran piutang (Receivable Turnover) untuk mengukur pengelolaan piutang perusahaan. Receivable Turnover adalah memberikan pandangan mengenai kualitas piutang perusahaan dan seberapa berhasilnya perusahaan dalam penagihannya. Semakin cepat arus kas masuk, semakin baik kemampuan perusahaan dalam memenuhi kewajiban-kewajibannya dan akhirnya dapat dibelikan kembali menjadi persediaan dan dijual kembali secara kredit dan menjadi piutang kembali.

Receivable Turnover in Days merupakan rasio yang menilai kebijakan rata-rata pengumpulan piutang dengan melakukan perbandingan hari dalam setahun (360) yang dengan perputaran piutang yang dihasilkan. Menurut Darsono (2009) Jika hari rata-rata pengumpulan piutang lebih besar dari pada jangka waktu yang telah ditentukan dalam perjanjian kredit, maka manajemen kurang baik dalam melakukan penagihan atau perusahaan mempunyai pelanggan yang kurang disiplin menetapi syarat-syarat kredit yang diberikan perusahaan. 
Total Asset Turnover merupakan efisiensi penggunaan total aktiva perusahaan untuk menghasilkan penjualan. Rasio ini melihat sejauhmana keseluruhan aset yang dimiliki perusahaan terjadi perputaran secara efektif. Menurut Prihadi (2007) semakin efektif perusahaan menggunakan asetnya, semain sedikit aset yang diperlukan. Dan ini penting karena dapat terlihat bagaimana pengelolaan yang dilakukan manajemen perusahaan dalam penggunaan aktiva di dalam perusahaan.Salah satu cara lain agar piutang dapat dikendalikan adalah dengan membuat skedul umur piutang (Aging Schedule) dalam skedul ini kita dapat mengendalikan piutang sehingga piutang macet dapat dihindari. Profitabilitas merupakan gambaran yang menunjukkan efektivitas manajemen dan efisiensi perusahaan secara keseluruhan yang ditujukan melalui besar kecilnya keuntungan yang diperoleh perusahaan berdasarkan penggunaan aset. Dalam penelitian ini penulis menggunakan rasio Return on Investment (ROI) untuk mengukur profitabilitas perusahaan industri dasar dan kimia sub sektor pakan ternak yang tercatat di BEI. Return on Investment (ROI) merupakan rasio yang melihat sejauh mana investasi yang telah ditanamkan apakah mampu memberikan pengembalian keuntungan sesuai dengan yang diharapkan.

Piutang ini merupakan salah satu cara untuk mempertahankan perusahaan pada saat ini, oleh karena itu perlu sekali bagi perusahaan melakukan pengelolaan piutang, hal ini menyangkut kegiatan arus kas perusahaan dan merupakan suatu tolak ukur dari keberhasilan perusahaan dalam penjualan kreditnya. Oleh karena itu, dibutuhkan pengelolaan piutang yang mampu menentukan kebijakan kredit dengan melihat untung dan ruginya terhadap kebijakan penjualan secara kredit tersebut (Harmono, 2011). Apabila suatu perusahaan dalam mengelola piutang yang dimilikinya tidak dilakukan dengan intensif maka akan berpengaruh terhadap laba yang dimiliki oleh perusahaan.

\subsection{Analisis Rasio Aktivitas}

Rasio aktivitas adalah rasio yang menggambarkan sejauh mana suatu perusahaan mempengaruhi sumber daya yang dimilikinya guna menunjang aktivitas perusahaan, Semakin tinggi perputaran semakin efektif penggunaan aset perusahaan. Rasio ini yang digunakan dalam pengukuran pengelolaan piutang usaha. Untuk menilai rasio aktivitas, digunakan yaitu (Asmirantho, 2013).

$$
\begin{gathered}
\text { Receivable Turnover }(\text { RTO })=\frac{\text { Annual Net Credit Sales }}{\text { Average Account Receivable }} \\
\text { Receivable Turnover in Days }(\text { RTD })=\frac{360}{\text { Receivable Turnover }} \\
\text { Total Asset Turnover }(\text { TATO })=\frac{\text { Sales }}{\text { Total Asset }}
\end{gathered}
$$

\subsection{Analisis Rasio Profitabilitas}

Rasio profitabilitas adalah rasio untuk mengukur efektivitas manajemen secara keseluruhan yang ditujukan oleh besar kecilnya tingkat keuntungan yang diperoleh dalam hubungannya dengan penjualan maupun investasi. Semakin baik rasio profitabilitas maka semakin 
baik kondisi kemampuan tingginya

profitabilitas salah

satunya perolehan keuntungan perusahaan menggunakan ROI, yaitu:

(Asmirantho, 2013). Perhitungan rasio

$$
\text { Return on Investment }(\text { ROI })=\frac{\text { Earnings after Tax }}{\text { Average Account Receivable }} \times 100 \%
$$

\section{Receivable Turnover (RTO)}

Rasio perputaran piutang usaha (Account Receivable Turnover) digunakan untuk mengukur sampai seberapa cepat perusahaan dapat mengumpulkan piutangnya. Piutang yang dimilki perusahaan mempunyai hubungan yang erat dengan volume penjualan kredit. Posisi piutang dan taksiran waktu pengumpulannya dapat dinilai dengan menghitung tingkat perputaran piuang tersebut yaitu dengan membagi total penjualan kredit dengan piutang rata-rata. (Munawir, 2010).

Semakin cepat perputaran piutang semakin efektif perusahaan dalam mengelola piutangnya (Riyanto,2010). Hal ini didukung oleh penelitian sebelumnya oleh Lutvianty (2013) perputaran piutang yang baik mengindikasikan bahwa perusahaan tersebut cukup baik dan efisien dalam mengelola piutangnya. Rasio perputaran piutang memberikan pemahaman tentang kualitas piutang dan kesuksesan penagihan piutang.Tingkat perputaran piutang atau Receivable Turnover dapat diketahui dengan cara perhitungan dilakukan sebagai berikut (Van Horne and Wachowicz, 2005) :

\section{Receivable Turn Over in Days (RTD)}

Rasio ini mengkaji tentang bagaimana suatu perusahaan melihat periode pengumpulan piutang yang akan terlihat. Periode terikatnya modal dalam piutang atau hari rata-rata pengumpulan piutang dapat dihitung dengan membagi tahun dalam hari dengan turnovernya. Hari rata-rata pengumpulan piutang dapat dihitung dengan cara sebagai berikut:

$$
\text { Receivable Turnover in Days }(\text { RTD })=\frac{360}{\text { Receivable Turnover }}
$$

Apabila hari rata-rata pengumpulan piutang selalu lebih besar dari pada batas waktu pembayaran yang telah ditetapkan tersebut berarti bahwacara pengumpulan piutangnya kurang efisien. (Riyanto, 2010). Menurut penelitian sebelumnya yang dilakukan Komang (2014) bahwa periode pengumpulan piutang berperan secara langsung dalam upaya mendukung peningkatan profitabilitas perusahaan.

\section{Total Asset Turnover (TATO)}


Total Asset Turnover ini penting bagi pemilik perusahaan dan penting lagi bagi manajemen perusahaan, karena hal ini akan menunjukan efisien tidaknya penggunaan seluruh aktiva di dalam perusahaan. Angka Assets
Turnover tinggi merupakan indikasi bahwa manajemen perusahaan telah mengelola harta perusahaan dengan baik. Perhitungan Total Assets Turnover dilakukan sebagai berikut : (Van Horne and Wachowicz, 2005)

$$
\text { Total Asset Turnover }(\text { TATO })=\frac{\text { Sales }}{\text { Total Asset }}
$$

\section{Aging Schedule}

Aging Schedule ini dapat digunakan untuk menilai baik komposisi piutang perusahaan, hal ini akan memberikan gambaran tentang proporsi dari masingmasing account selama periode tertentu. Adanya informasi dari skedul umur piutang ini akan menandakan atau dapat mengetahui berapa banyak piutang yang masih dalam masa pembayaran dan piutang mana yang sudah melawati masa pembayaran serta perlu melakukan tindakan dan kebijakan serius yang perlu dilakukan perusahaan.

\section{Return on Investment (ROI)}

Return on Investment merupakan rasio yang menggambarkan dan memberikan peramalan berapa besar jumlah keuangan yang sedang terjadi di suatu perusahaan. Rasio ini juga memberikan gambaran tentang tingkat kemampuan manajemen perusahaan mengelola dana perusahaan awal dan akhir periode. Semakin tinggi tingkat pengembalian investasi (ROI) suatu perusahaan maka semakin baik pula keadaan perusahaan mengelola investasi perusahaan sehingga menghasilkan laba yang maksimal. ROI dapat dihitung dengan rumus:

\section{Return on Investment $($ ROI $)=\frac{\text { Earnings after Tax }}{\text { Average Account Receivable }} \times 100 \%$}

Adapun Hipotesis penelitiannya :

1. Pengelolaan piutang pada perusahaan industri kimia dan dasar sub sektor pakan ternak yang tercatat di BEI (CPIN, JPFA, SIPD), masih belum optimal. Karena waktu penagihan piutangnya memiliki waktu yang panjang.

2. Kemampuan dalam menghasilkan laba perusahaan pada industri kimia dan dasar sub sektor pakan ternak yang tercatat di BEI (CPIN, JPFA, SIPD) dilihat dari pemberian piutang namun dari penjualannya mengalami masih fluktuasi walapupun adanya peningkatan namun masih tergolong lambat. Hal ini mempengaruhi laba yang diterima perusahaan.

3. Terdapat pengaruh pengelolaan piutang usaha terhadap kemampuan dalam menghasilkan 
laba perusahaan pada perusahaan industri kimia dan dasar sub sektor pakan ternak yang tercatat di BEI (CPIN, JPFA, SIPD).

1) Receivable Turnover memiliki pengaruh positif terhadap Return on Investment pada perusahaan industri kimia dan dasar sub sektor pakan ternak yang tercatat di BEI (CPIN, JPFA, SIPD). Semakin tinggi perputaran piutang semakin baik pengelolaan piutang perusahaan.

2) Receivable Turnover in Days memiliki pengaruh negatif terhadap Return on Investment pada industri kimia dan dasar sub sektor pakan ternak yang tercatat di BEI (CPIN, JPFA, SIPD). Semakin lama rata-rata pengumpulan piutang semakin buruk bagi perusahaan.

3) Total Asset Turnover memiliki pengaruh positif terhadap Return on Investment pada perusahaan industri kimia dan dasar sub sektor pakan ternak yang tercatat di BEI (CPIN, JPFA, SIPD). Semakin tinggi TATO maka semakin efisien pengelolaan piutang perusahaan.

4) Receivable Turnover, Receivable Turn Over in Days dan Total Asset Turnover memiliki pengaruh positif terhadap Return on Investment pada perusahaan industri kimia dan dasar sub sektor pakan ternak yang tercatat di BEI (CPIN, JPFA, SIPD).

III. Metode Penelitian

3.1. Jenis, Metode dan Teknik Penelitian

1. Jenis Penelitian, Dalam penelitian ini, Jenis penelitian yang digunakan adalah penelitian asosiatif (hubungan) dimana penelitian asosiatif merupakan penelitian yang bertujuan untuk mengetahui pengaruh ataupun juga hubungan antar dua variabel atau lebih. (Ghozali, 2005).

2. Metode Penelitian, Metode penelitian yang digunakan adalah metode historis, yaitu dimana dalam memecahkan masalah penelitian menggunakan data-data pada waktu lalu.

3. Teknik Penelitian, Teknik penelitian yang digunakan dalam penelitian ini adalah teknik statistik inferensial, termasuk dalam statistik parametrik, yaitu statistik yang mempertimbangkan jenis sebaran/ distribusi data yang berdistribusi normal dan memiliki varian homogen. Pada umumnya, data yang digunakan dalam statistik parametrik ini bersifat interval dan rasio.

\subsection{Unit Analisis}

Unit analisis yang digunakan dalam penelitian ini adalah PT. Charoen Pokphand Indonesia (CPIN), PT. Japfa Comfeed Indonesia (JPFA), PT. Sierad Produce (SIPD).

\subsection{Prosedur Pengumpulan Data:}

1. Data Sekunder, Penelitian data sekunder adalah data yang sudah dipublikasikan di berbagai media, pengumpulan data ini dengan pengamatan secara tidak langsung terhadap objek yang diteliti untuk mendapatkan data yang diperlukan dalam penelitian ini melalui internet yang diperoleh melalui situs http://www.idx.co.id.

2. Studi Pustaka, Dengan cara memperoleh data tambahan melalui literatur-literatur yang berhubungan dengan masalah yang diteliti sebagai bahan pertimbangan penelitian yang dilakukan dan juga menggunakan buku-buku 
tambahan lainnya yang ada kaitannya dengan masalah yang diteliti.

\subsection{Metode Analisis}

1. Pengelolaan piutang usaha menggunakan rasio aktivitas
a) Perputaran Piutang
(Receivable Turnover)
b) Perputaran piutang dalam hari (Receivable Turnover in Days)
c) Perputaran aktiva (Total Asset turnover)

2. Aging Schedule (Skedul Umur Piutang) digunakan dalam pengelolaan piutang usaha.

3. Kemampuan dalam menghasilkan laba dengan menggunakan rasio profitabilitas Return on Investment (ROI)

4. Pengaruh Pengelolaan Piutang Terhadap Kemampuan Dalam Mengahsilkan Laba Perusahaan Pada Perusahaan Industri Dasar dan Kimia Sub Sektor Pakan Ternak Yang Tercatat di BEI

\subsubsection{Uji Asumsi Klasik}

1. Uji Normalitas, metode uji normalisasi akan dilakukan dengan menggunakan uji one simple Kolmogorov smirnov. Model regresi yang baik adalah yang memiliki nilai residual yang terdistribusi secara normal. (Priyatno, 2012)

2. Uji Multikolinearitas, pada penelitian ini akan dilakukan uji multikolinearitas dengan metode uji Tolerance dan inflation factor (VIF) pada model regresi. Pada model regresi yang baik seharusnya tidak terjadi korelasi yang sempurna atau mendekati sempurna diantara variabel bebas (korelasinya 1 atau mendekati 1).
3. Uji Heteroskedastisitas, pada penelitian ini dilakukan uji heteroskedastisitas dengan menggunakan uji Glejser. Model regresi yang baik adalah tidak tejadi heteroskedastisitas.

4. Uji Autokorelasi, model regresi yang baik adalah yang tidak terdapat masalah autokorelasi. Pada Penelitian ini akan dilakukan uji autokorelasi dengan menggunakan uji Durbin - watson (DW test).

\subsubsection{Analisis Regresi Linier Berganda}

Pengaruh Pengelolaan Piutang Terhadap Kemampuan Dalam Menghasilkan Laba Perusahaan :

$$
Y^{\prime}=a+b_{1} X_{1}+b_{2} X_{2}+b_{3} X_{3}
$$

Keterangan :

$Y=$ Return On Investment (ROI)

$X_{1}=$ Receivable Turnover $(R T O)$

$X_{2}=$ Receivable Turnover in Days (RTD)

$X_{3}=$ Total Asset Turnover (TATO)

$a=$ Konstanta, yaitu nilai $\mathrm{Y}$ jika $\mathrm{X}_{1}$, $\mathrm{X}_{2}, \mathrm{X}_{3}=0$

$b=$ Koefisien regresi, yaitu nilai peningkatan atau penurunan variabel $\mathrm{Y}$ yang didasarkan variabel $\mathrm{X}_{1}, \mathrm{X}_{2}$ dan $\mathrm{X}_{3}$.

\subsubsection{Uji Hipotesis}

1. Uji F (Simultan), digunakan untuk mengetahui apakah secara bersama-sama variabel independen berpengaruh signifikan, terhadap variabel dependen, dalam hai ini untuk mengetahui apakah Receivable Turnover, Receivable Turnover in Days, dan Total AssetsTurnover berpengaruh secara signifikan atau tidak terhadap Return On Investment. Pengujian menggunkan tingkat signifikan 0,05 . 
2. Uji t (Parsial), digunakan untuk mengetahui apakah secara parsial variabel independen berpengaruh secara signifikan atau tidak terhadap variabel dependen dengan pengujian menggunakan tingkat signifikansi 0.05 dan 2 sisi.

\section{HASIL PENELITIAN}

4.1. Pengelolaan Piutang Perusahaan Industri Dasar dan Kimia Sub Sektor Pakan Ternak yang Tercatat di BEI (CPIN, JPFA, SIPD)

Kondisi Pengelolaan piutang perusahaan diketahui dari hasil perhitungan rasio diketahui bahwa Receivable Turnover dan Receivable Turnover in Days untuk semua perusahaan pada periode tahun 20042013 mengalami fluktuasi dan peningkatan yang lambat. Selain itu diketahui untuk perusahaan PT. Charoen Pokphand Indonesia tbk (CPIN), PT. Japfa Comfeed Indonesia Tbk (JAPFA), dan PT. Sierad Produce Tbk (SIPD) memiliki nilai rata-rata yang berada dibawah rata-rata. Hal ini disebabkan perusahaan kurang efisien dalam proses penagihan pada beberapa pelanggan yang mengalami kesulitan dalam membayar hutangnya dan penjualan secara tunai lebih tinggi dibandingkan dengan penjualan secara kredit (piutang). Untuk Total Asset Turnover setiap tahunnya mengalami peningkatan dan berfluktuasi pada periode 2004-2013 perusahaan masih belum optimal dan efisien dalam memutar dan menggunakan aktivanya dalam menghasilkan penjualan karena terlihat pada setiap perusahaan walaupun mengalami peningkatan tapi peningkatan yang tergolong lambat dan masih berfluktuasi.

\subsection{Kemampuan Menghasilkan Laba pada Perusahaan Industri Dasar dan Kimia Sub Sektor Pakan Ternak yang Tercatat di BEI (CPIN, JPFA, SIPD)}

Kemampuan dalam menghasilkan laba perusahaan dilihat dari perhitungan Return on Investment berfluktuasi dan tergolong lambatpada setiap tahunnya. kondisi perusahaan masih belum optimal dan efektif dalam menghasilkan laba perusahaan dan memutar aset yang dimilikinya. Terlihat masih adanya fluktuasi dari hasil yang diperoleh maka berpengaruh terhadap laba yang diperoleh perusahaan. kondisi ini terjadi karena perusahaan memiliki nilai yang berada dibawah rata-rata.

\subsection{Pengaruh Pengelolaan Piutang terhadap Kemampuan Dalam Menghasilkan Laba Perusahaan pada Perusahaan Industri Dasar dan Kimia Sub Sektor Pakan Ternak yang Tercatat di BEI ( CPIN, JPFA, SIPD )}

\subsubsection{Pengujian Asumsi Klasik}

\section{Uji Normalitas}

One-Sample Kolmogorov-Smirnov Test

\begin{tabular}{|ll|r|}
\hline & & $\begin{array}{c}\text { Unstandardize } \\
\text { d Residual }\end{array}$ \\
\hline $\mathrm{N}$ & & 30 \\
Normal Parameters & Mean & $0 \mathrm{E}-7$ \\
Most Extreme & Std. Deviation & 7.39652651 \\
Differences & Absolute & .085 \\
& Positive & .085
\end{tabular}




\begin{tabular}{|l|r|}
\multicolumn{1}{|c|}{ Negative } & -.042 \\
Kolmogorov-Smirnov Z & .466 \\
Asymp. Sig. (2-tailed) & .982 \\
\hline
\end{tabular}

a. Test distribution is Normal.

b. Calculated from data.

Berdasarkan output tabel One Sample

Kolmogorov Sminnov Testdiketahui nilai signifikansi (Asymp.sig 2-tailed) sebesar 0,982 lebih besar dibandingkan dengan taraf signifikansi sebesar 0,05 (0,982 > $0,05)$, maka residual terdistribusi dengan normal.

Coefficients $^{\mathbf{a}}$

\begin{tabular}{|c|c|c|c|c|c|c|c|}
\hline \multirow[t]{2}{*}{ Model } & \multicolumn{2}{|c|}{$\begin{array}{c}\text { Unstandardized } \\
\text { Coefficients }\end{array}$} & $\begin{array}{l}\text { Standardized } \\
\text { Coefficients } \\
\end{array}$ & \multirow[t]{2}{*}{$\mathrm{t}$} & \multirow[t]{2}{*}{ Sig. } & \multicolumn{2}{|c|}{$\begin{array}{c}\text { Collinearity } \\
\text { Statistics }\end{array}$} \\
\hline & B & Std. Error & Beta & & & Tolerance & VIF \\
\hline (Constant) & -55.411 & 18.130 & & -3.056 & .005 & & \\
\hline RTO & .655 & .399 & .380 & 1.642 & .113 & .220 & 4.536 \\
\hline $\begin{array}{ll}1 & \text { RTD }\end{array}$ & .479 & .309 & .405 & 1.547 & .134 & .173 & 5.797 \\
\hline TATO & 21.534 & 3.303 & .905 & 6.520 & .000 & .612 & 1.634 \\
\hline
\end{tabular}

a. Dependent Variable: ROI

(Sumber Data : Hasil olahan data program SPSS, 20)

2. Uji Multikolinearitas

Berdasarkan hasil output tabel, diketahui bahwa nilai VIF kurang dari 10 dan nilai tolerance lebih dari 0,1 untuk ketiga variabel, maka dapat disimpulkan tidak terjadi masalah multikolinieritas pada model regresi bebas dari multikolinieritas, yaitumempunyai nilai VIF (Variance inflation Factor) kurang dari 10 dan mempunyai angka tolerance lebih dari 0,1 .

Coefficients $^{\mathrm{a}}$

\begin{tabular}{|c|c|c|c|c|c|}
\hline \multirow[t]{2}{*}{ Model } & \multicolumn{2}{|c|}{$\begin{array}{c}\text { Unstandardized } \\
\text { Coefficients }\end{array}$} & $\begin{array}{c}\text { Standardized } \\
\text { Coefficients }\end{array}$ & \multirow[t]{2}{*}{$\mathbf{t}$} & \multirow[t]{2}{*}{ Sig. } \\
\hline & $\mathrm{B}$ & Std. Error & Beta & & \\
\hline (Constant) & 12.622 & 10.591 & & 1.192 & .244 \\
\hline RTO & -.322 & .233 & -.537 & -1.381 & .179 \\
\hline RTD & -.179 & .181 & -.436 & -.992 & .330 \\
\hline TATO & 1.630 & 1.929 & .197 & .845 & .406 \\
\hline
\end{tabular}

1. Dependent Variable: ABS_RES

(Sumber Data : Hasil olahan data program SPSS,20)

3. Uji Heteroskedastisitas

JIMFE (Jurnal Ilmiah Manajemen Fakultas Ekonomi)

Volume 2 No. 1 Tahun 2016 Edisi 2, Hal. 53-66 
Dari output tabel, diketahui bahwa nilai signifikansi ketiga variabel independen yaitu Receivable Turnover (RTO) (0,179),

Receivable Turnover in Days (RTD) (0,330), dan Total Asset
Turnover (TATO) (0,406) lebih dari 0,05. Dengan demikian dapat disimpulkan bahwa tidak terjadi masalah heteroskedastisitas pada model regresi.

4. Uji Autokorelasi

Model Summary ${ }^{b}$

\begin{tabular}{|l|r|r|r|r|r|}
\hline Model & $\mathrm{R}$ & $\mathrm{R}$ Square & $\begin{array}{c}\text { Adjusted R } \\
\text { Square }\end{array}$ & $\begin{array}{c}\text { Std. Error of the } \\
\text { Estimate }\end{array}$ & Durbin-Watson \\
\hline 1 & $.892^{\mathrm{a}}$ & .796 & .762 & 6.63087 & 1.898 \\
\hline
\end{tabular}

a. Predictors: (Constant), RTO, RTD, TATO

2. Dependent Variable: ROI

(Sumber Data : Hasil olahan data program SPSS,20)

Hasil uji autokorelasi pada tabel, diketahui nilai Durbin-Watson sebesar 1,898. Nilai DU dan DL dapat diperoleh dari tabel statistik Durbin-Watson. Dengan $\mathrm{n}=30$, dan $\mathrm{k}=3$ maka didapat nilai $\mathrm{DU}=1,6498$ dan $\mathrm{DL}=1,2138$. Jadi didapat nilai 4-DU $=2,3502$ dan nilai 4$\mathrm{DL}=2,7862$. Karena nilai DU < DW < 4-DU $=1,6498<1,898<2,3502$ maka dapat disimpulkan tidak terjadi autokorelasi pada model regresi.

\section{Uji Regresi Linier Berganda}

\begin{tabular}{|l|c|r|r|r|}
\hline Model & R & R Square & Adjusted R Square & Std. Error of the Estimate \\
\hline 1 & $.833^{\mathrm{a}}$ & .693 & .658 & 7.81160 \\
\hline
\end{tabular}

a. Predictors: (Constant), TATO, RTO, RTD

3. Dependent Variable: ROI

a) Angka $\mathrm{R}$ yang didapat adalah 0,833 yang berarti korelasi antara RTO, RTD dan TATO terhadap ROI sebesar 0,833 atau $83,3 \%$.

b) $\mathbf{R}$ Square $\left(\mathbf{R}^{2}\right)$ persentase sumbangan pengaruh variabel RTO, RTD dan TATO terhadap ROI sebesar 69,3\%. c) Adjusted $\mathbf{R}$ Square, adalah $R$ Square yang telah disesuaikan, nilai sebesar 0,658 atau $65,8 \%$.

d) Standard Error of the Estimate, adalah ukuran kesalahan prediksi, nilai sebesar 7.81160. Artinya kesalahan yang dapat terjadi dalam memprediksi Return On Investment sebesar 7.81160.

\section{Uji Hipotesis}

\section{(1) Uji F}

\section{ANOVA}




\begin{tabular}{|c|c|c|c|c|c|c|}
\hline \multicolumn{2}{|c|}{ Model } & $\begin{array}{c}\text { Sum of } \\
\text { Squares }\end{array}$ & Df & Mean Square & $\mathrm{F}$ & Sig. \\
\hline \multirow{3}{*}{1} & Regression & 3584.178 & 3 & 1194.726 & 19.579 & $.000^{b}$ \\
\hline & Residual & 1586.550 & 26 & 61.021 & & \\
\hline & Total & 5170.728 & 29 & & & \\
\hline
\end{tabular}

a. Dependent Variable: ROI

b. Predictors: (Constant), TATO, RTO, RTD

Hasil uji $F$ atau uji koefisien regresi secara bersama-sama. Uji $\mathrm{F}$ digunakan untuk mengetahui apakah secara bersama-sama variabel independen berpengaruh signifikan terhadap variabel dependen. Dari output tabel 4.12. diperoleh $\mathrm{F}$ hitung sebesar 19,579. F tabel dapat dilihat pada tabel statistik distribusi $F$ pada tingkat signifikansi 0,05 dengan df 1 (jumlah variabel-1) $=3$, dan df 2 (n-k-1) atau $30-3-1=26$ (n adalah jumlah data dan $\mathrm{k}$ adalah jumlah variabel independen), hasil diperoleh untuk F tabel sebesar 2,98. Karena hasil $\mathrm{F}$ hitung > F tabel $(19,579>2,975)$ maka Ho ditolak. Jadi dapat disimpulkan bahwa Receivable Turnover, Receivable Turnover in Days dan Total Asset Turnover secara bersama-sama berpengaruh signifikan terhadap Return on

\section{(2) Uji t}

\section{Coefficients $^{\mathrm{a}}$}

\begin{tabular}{|l|r|r|r|r|r|}
\hline \multirow{2}{*}{ Model } & \multicolumn{2}{|c|}{ Unstandardized Coefficients } & Standardized Coefficients & \multirow{2}{*}{$\mathrm{t}$} & \multirow{2}{*}{ Sig. } \\
\cline { 2 - 5 } & \multicolumn{1}{|c|}{$\mathrm{B}$} & \multicolumn{1}{c|}{ Std. Error } & Beta & & \\
\hline (Constant) & -55.411 & 18.130 & & -3.056 & .005 \\
RTO & .655 & .399 & .380 & 1.642 & .113 \\
1 & .479 & .309 & .405 & 1.547 & .134 \\
RTD & 21.534 & 3.303 & .905 & 6.520 & .000 \\
\hline
\end{tabular}

a. Dependent Variable: ROI

a) Nilai $\mathrm{t}$ hitung untuk Receivable Turnover adalah 1,642. Karena nilai $\mathrm{t}$ hitung $<\mathrm{t}$ tabel $(1,642<$ 2,056) maka Ho diterima. Jadi dapat disimpulkan bahwa Receivable Turnover secara parsial tidak berpengaruh positif dan tidak signifikan terhadap Return on Investment.

b) Nilai t hitung untuk Receivable Turnover in Days adalah 1,547 Karena nilai $\mathrm{t}$ hitung $<\mathrm{t}$ tabel $(1,547<2,056)$ maka Ho diterima. Jadi dapat disimpulkan bahwa Receivable Turnover in Days secara parsial tidak berpengaruh positif dan tidak signifikan terhadap Return on Investment.

a. Nilai t hitung untuk Total Asset Turnover adalah 6,520. Karena nilai $\mathrm{t}$ hitung > $\mathrm{t}$ tabel $(6,520>$ 2,056) maka Ho ditolak. Jadi dapat disimpulkan bahwa Total Asset Turnover secara parsial berpengaruh positif dan signifikan terhadap Return on Investment.

\subsection{Pengaruh Receivable Turnover terhadap Return on Investment pada Perusahaan industri Dasar}


dan Kimia sub Sektor Pakan

Ternak yang Tercatat di BEI

Hasil hipotesis uji $\mathrm{t}$ diketahui bahwa Receivable Turnover secara parsial tidak berpengaruh positif dan tidak signifikan terhadap Return on Investment. Karena nilai $\mathrm{t}$ hitung $<\mathrm{t}$ tabel $(1,642<2,056)$ dan nilai signifikansi yang dihasilkan sebesar 0,113>0,05.

1. Pengaruh Receivable Turnover in Days terhadap Return on Investment pada Perusahaan Dasar dan Kimia Sub Sektor PakanTernak yang Tercatat di BEI

Hasil hipotesis uji t diketahui bahwa Receivable Turnover InDayssecara parsial tidak berpengaruh positif dan tidak signifikan terhadap Return on Investment. Karena nilai t hitung < t tabel $(1,547<2,056)$ dan dengan nilai signifikansi yang dihasilkan sebesar 0,134>0,05.

2. Pengaruh Total Asset Turnover terhadap Return on Investment pada perusahaan Dasardan Kimia Sub Sektor PakanTernak yang Tercatat di BEI'

Hasil pengujian hipotesis uji t, diketahui bahwa Total Asset Turnover secara parsial berpengaruh positif dan signifikan terhadap Return on Investment. Karena nilai $\mathrm{t}$ hitung $>\mathrm{t}$ tabel $(6,520>2,056)$ dan nilai signifakansi yang dihasilkan sebesar $0,000<0,05$.

3. Pengaruh Receivable Turnover, Receivable Turnover in Days, dan Total Asset Turnover terhadap Return on Investment pada Perusahaan Dasar dan Kimia yang Tercatat di BEI

Hasil pengujian hipotesis uji $\mathrm{F}$ diketahui bahwa Receivable Turnover, Receivable Turnover in Days, dan Total Asset Turnover secara simultan berpengaruh signifikan terhadap Return on Investment. Karena hasil $\mathrm{F}$ hitung $>\mathrm{F}$ tabel $(19,579>2,975)$ dengan nilai signifikansi yang dihasilkan sebesar $0,000<0,05$.

\section{Penutup}

5.1. Simpulan

Simpulan Umum

1. Industri pakan ternak sangat berperan dalam industri peternakan di Indonesia.

2. Rangkaian kegiatan perusahaan bergerak dalam bidang beberapa unit usaha yaitu produksi dan perdagangan pakan ternak, pengolahan berbagai macam bahan makanan, dan pembibitan atau pengembangbiakan unggas.

\section{Simpulan Khusus}

1. Pengelolaan piutang yang dilakukan PT. Charoen Pokphand Indonesia Tbk (CPIN), PT. Japfa Comfeed Indonesia Tbk (JPFA) dan PT. Sierad Produce Tbk (SIPD) tingkat penjualan kredit (piutang) mengalami fluktuasi dan peningkatan yang lambat pada setiap perusahaan periode 20042013.

2. Kemampuan dalam menghasilkan laba perusahaan pada perusahaan PT. Charoen Pokphand Indonesia Tbk (CPIN), PT. Japfa Comfeed Indonesia Tbk (JPFA) dan PT. Sierad Produce Tbk (SIPD)berfluktuasi pada setiap tahunnya. Hal ini mengindikasikan adanya ketidakstabilan peningkatan dan penurunan Return on Investment dari hasil perhitungan Receivable Turnover, Receivable Turnover in Days dan Total Asset Turnoveryang mengalami peningkatan namun tidak diiringi dengan peningkatan pada Return on 
Investment yang dihasilkan perusahaan.

3. Secara simultan variabel independen yang diukur dengan Receivable Turnover, Receivable Turnover in Daysdan Total Asset Turnoverberpengaruh terhadap kemampuan dalam menghasilkan laba perusahaan yang diukur dengan Return on Investment. Hal tersebut dapat dilihat dari nilai $\mathrm{F}$ hitung lebih besar dibandingkan dengan $F$ tabel $(19,579>2,975)$. Sementara secara parsial pengaruh Receivable Turnover, Receivable Turnover in Daysdan Total Asset Turnover disimpulkan sebagai berikut : (1) Nilai $t$ hitung Receivable Turnover lebih kecil dibandingkan nilai t tabel $(1,642<$ 2,056) dapat disimpulkan bahwa Receivable Turnovertidak berpengaruh positif dan tidak signifikan terhadap Return on Investment. (2) Nilai t hitung Receivable Turnover in Days lebih kecil dibandingkan nilai $\mathrm{t}$ tabel $(1,547<2,056)$ dapat disimpulkan bahwa Receivable Turnover in Days tidak berpengaruh positif dan tidak signifikan terhadap Return on Investment. (3) Nilai t hitung Total Asset Turnover lebih besar dibandingkan $\mathrm{t}$ tabel $(6,520>$ 2,056) dapat disimpulkan bahwa Total Asset Turnover berpengaruh positif dan signifikan terhadap Return on Investment.

\subsection{SARAN}

1. Perusahaan harus mempertimbangkan sebelum memutuskan kebijakan-kebijakan kredit yang akan diberlakukan bagi perusahaan.

2. Perusahaan harus lebih memperketat, mengontrol dan menganalisis serta mengawasi kebijakan pemberian piutang dan pengumpulan piutangnya.

3. Memperhatikan dana yang akan diinvestasikan kedalam piutang.

4. Perusahaan harus bisa memilih pelanggan.

\section{DAFTAR PUSTAKA}

Arthur J.Keown, Jonh D. Martin J. William Petty, David F.Scott (2002), Financial Management, Principle and Application, Ninth Edition, New Jersey, USA,Pearson Education, Inc.

BodieZvi, Kane Alex \& Marcus Alan J. (2008), Essentials of Investments. Sevent Edition. NewYork: McGraw-Hill/Irwin

Bambang Riyanto (2010), Dasar-Dasar Pembelanjaan Perusahaan, Edisi Keempat, Cetakan Kesepuluh, Yogyakarta, BPFE.

Darsono Prawironegoro (2009).

Manajemen Keuangan. Nusantara Consulting. Jakarta

Edhi Asmirantho (2013), Financial Management, Learning Books, Pakuan University.

Edhi Asmirantho (2014), Effect of Financial Fundamental Factors and Macroeconomics to Stock Return with Implications on Corporate Value (Tobin's Q) Real Estate and Property Go Public in Indonesia, Journal of Business and Management (JOBMAN), Vol. 1 No.1, Januari 2014. ISSN : 23551240.

Eugene F. Brigham, Louis C. Gapenski (1997), Financial Management, Theory and Practice, Eighth Edition, The Dryden Press, Orlando, USA.

Imam Ghozali (2005), Aplikasi Analisis dan Multivariate dengan Program SPSS., Edisi 1, Semarang, Badan Penerbit Universitas Diponegoro. 
Luh Komang Suarnami, I Wayan Suwendra, Wayan Cipta (2014), Pengaruh Perputaran Piutang Dan Periode Pengumpulan Piutang Terhadap Profitabilitas Pada Perusahaan Pembiayaan. eJournal Bisma Universitas Pendidikan Ganesha Jurusan Manajemen (Volume 2 Tahun 2014).

Lutvianty K. Napu.(2013), Pengaruh Perputaran Piutang Terhadap
Rentabilitas Pada Perusahaan Properti Yang Terdaftar Di Bursa Efek Indonesia.Fakultas Ekonomi dan Bisnis.Universitas Negeri Gorontalo.

Toto Prihadi. 2007. Mudah Memahami Laporan Keuangan. PPM. Jakarta.

Van Horne, James C. and Jhon M, Wochowicz, Jr (2005), Fundamental of Financial Management, Tenth Edition, New Jersey, USA., Prentice - Hall, Inc. 